\title{
DOES INTERNATIONAL TOURISM PROMOTE ECONOMIC GROWTH? SOME EVIDENCE FROM INDONESIA
}

\author{
Martahadi MARDHANI \\ Universitas Syiah Kuala (USK), Faculty of Economics and Business, Banda Aceh, Indonesia \\ Universitas Samudra (UNSAM), Faculty of Economics, Langsa, Indonesia, e-mail: martahadi@ unsam.ac.id
}

M. Shabri Abd. MAJID*

Universitas Syiah Kuala (USK), Faculty of Economics and Business, Banda Aceh, Indonesia, e-mail: mshabri@unsyiah.ac.id

\author{
Abd. JAMAL \\ Universitas Syiah Kuala (USK), Faculty of Economics and Business, Banda Aceh, Indonesia, e-mail: abdjamal@ unsyiah.ac.id \\ Said MUHAMMAD \\ Universitas Syiah Kuala (USK), Faculty of Economics and Business, Banda Aceh, Indonesia, e-mail: said@unsyiah.ac.id
}

\begin{abstract}
Citation: Mardhani, M., Majid, M.S.A., Jamal, A., \& Muhammad, S. (2021). DOES INTERNATIONAL TOURISM PROMOTE ECONOMIC GROWTH? SOME EVIDENCE FROM INDONESIA. GeoJournal of Tourism and Geosites, 37(3), 775-782. https://doi.org/10.30892/gtg.37306-708
\end{abstract}

\begin{abstract}
Realizing an increasing contribution of the tourism sector to global economies, this study intends to enrich the existing tourism literature by empirically exploring the short- and long-run dynamic causalities between tourism and economic growth in Indonesia over the period 1995 to 2017. For these purposes, cointegration, Fully Modified Least Squares (FMOLS), and Granger causality techniques are adopted. The study found a cointegration between tourism and economic growth, indicating the existence of a long-run relationship between the tourism sector and economic growth. In the long-run, tourism has contributed to the promotion of economic growth. Finally, both in the short- and long-run, the study found a unidirectional causal relationship running from tourism to economic growth, confirming the tourism-led growth hypothesis. To enhance Indonesia's economic growth, the tourism sector should be further promoted by making it more attractive, supported by advanced IT facilities, warm hospitality, and diversified tourism objects.
\end{abstract}

Key words: cointegration, dynamic causality, economic growth, tourism-led growth, tourism receipts

\section{INTRODUCTION}

Undeniably, the tourism sector has contributed to the development of global economies. The World Tourism Organization (UNWTO, 2018) reported that, globally, international tourists had reached 1,323 million visits with an annual growth rate of $6.8 \%$ in 2017. These figures have been far from only $3.8 \%$ predictions of annual tourism growth from 2010 to 2020, which is the highest increase since the 2008 global financial crisis. This increase has reached the level of revenue of USD1.340 billion (4.9\%) in 2017 and ranked the top three after the chemicals and fuels sector in the export category, especially in developing countries. Whereas for Indonesia, UNWTO (2018) reported an increase in revenues from international tourism visits from USD11.206 million in 2016 to USD12.520 million in 2017, with a contribution of 3.2\% of total international tourism visits to the Asia and Pacific region. To ensure the sustainability of the international tourism market in Indonesia, the Republic of Indonesia's Government has a strong commitment to promoting the tourism sector as one of the mainstay sectors by initiating Government Regulation No. 50 of 2011, concerning the National Tourism Development Master Plan. This regulation contains the vision, mission, goals, objectives, and direction of national tourism development for the 2010-2025 period. Strengthening national tourism destination areas is an important strategy to develop the tourism sector (Kang et al., 2014). In Indonesia's case, the development of destination areas for international markets must be carried out sustainably to promote the economy due to declining oil and gas exports over the past decade.

This is in accordance with the recent study by Hurri et al. (2019) for the island of Sumatra, Indonesia, which found that the contribution of exports from oil and gas has been declining for a decade, and currently, the economy is supported by the non-oil and gas sector, especially tourism sector. Previous studies on the contribution of tourism to the economy have found mixed findings. For example, there has been plenty of empirical evidence supporting the tourismled growth hypothesis (Narayan, 2010; Eeckels et al., 2012; Kadir et al., 2012; Srinivasan et al., 2012; Hye and Khan, 2013; Tang and Tan, 2015; Govdeli and Direkci, 2017). The results of their investigation showed that tourism influences economic growth, validating the tourism-led growth hypothesis. On the contrary, Oh (2005) found that tourism is affected by economic growth, confirming the growth-led tourism hypothesis. Additionally, there have also been studies

\footnotetext{
${ }^{*}$ Corresponding author
} 
that suggest a two-way causality between tourism and economic growth (Aslan, 2014; Balcilar et al., 2014; Bilen et al., 2017; and Dogru and Bulut, 2018). This finding indicates a feedback hypothesis between tourism and economic growth. Finally, Arslanturk et al. (2011) found no causality relationship between tourism and economic growth (Arslanturk et al., 2011), showing the independence of tourism from economic growth.

By including Indonesia as one of the investigated countries, Eyuboglu and Eyuboglu (2020) find a causality running from economic growth to tourism in the Indonesian economy, supporting the growth-led tourism hypothesis. Instead, Sokhanvar et al. (2018) also included Indonesia in their investigation and found no significant relationship between tourism and economic growth in Indonesia. Both of these studies found mixed findings, but none of them proved that the tourismled growth hypothesis is valid for Indonesia's case. The existence of mixed findings of the tourism-economic growth relationships has motivated our present study to provide the latest empirical findings on tourism-economy literature. Which hypothesis is the most relevant to Indonesia's economic growth related to the tourism contribution? Is it a tourism-led hypothesis or growth-led hypothesis or non-causal effect, or bidirectional effect where both tourism and economic growth affect each other? Considering these important questions to be answered, it provides important implications for promoting economic growth through the tourism sector; thus, this study intends to probe these issues.

Table 1. Summary of literature review

\begin{tabular}{|c|c|c|c|c|}
\hline Author & Country & Period & Variables & Results \\
\hline Arslanturk et al. (2011) & Turkey & $1963-2006$ & GDP, tourism receipts & Tourism $\neq$ Growth \\
\hline Amaghionyeodiwe (2012) & Jamaica & $1970-2005$ & GDP, tourism receipts & Tourism $\rightarrow$ Growth \\
\hline Antonakakis et al. (2015) & 10 European countries & $1995-2012$ & GDP, tourism receipts & Tourism $\rightarrow$ Growth \\
\hline Antonakakis et al. (2019) & 113 countries & $1995-2014$ & GDP, tourism receipts & Tourism $\rightarrow$ Growth \\
\hline Aratuo and Etienne (2019) & United States & 1998-2017 & GDP, tourism receipts & Tourism $\leftrightarrow$ Growth \\
\hline Aslan (2014) & 12 Mediterranean countries & $1995-2010$ & GDP, tourism receipts & Tourism $\leftrightarrow$ Growth \\
\hline $\begin{array}{l}\text { Balaguer and Cantavella-Jordá } \\
(2002)\end{array}$ & Spain & $\begin{array}{l}\text { 1975:Q1- } \\
\text { 1997:Q1 }\end{array}$ & $\begin{array}{l}\text { GDP, tourism receipts, } \\
\text { exchange rate }\end{array}$ & Tourism $\rightarrow$ Growth \\
\hline Balcilar et al. (2014) & South Africa & 1960-2011 & GDP, tourism receipts & Tourism $\leftrightarrow$ Growth \\
\hline Bilen et al. (2017) & 12 Mediterranean countries & $1995-2015$ & GDP, tourism receipts & Tourism $\leftrightarrow$ Growth \\
\hline Chulaphan and Barahona (2018) & Thailand & $2008-2015$ & GDP, tourism arrivals & Tourism $\leftrightarrow$ Growth \\
\hline Dogru and Bulut (2018) & 7 European Countries & 1996-2014 & GDP, tourism receipts & Tourism $\leftrightarrow$ Growth \\
\hline Eeckels et al. (2012) & Greece & 1976-2004 & GDP, tourism receipts & Tourism $\rightarrow$ Growth \\
\hline Eyuboglu and Eyuboglu (2020) & 9 emerging countries & 1995-2016 & $\begin{array}{l}\text { GDP per capita, } \\
\text { tourism receipts }\end{array}$ & $\begin{array}{l}\text { Tourism } \rightarrow \text { Growth: } \\
\text { Tourism } \neq \text { Growth }\end{array}$ \\
\hline Govdeli and Direkci (2017) & 34 OECD countries & $1997-2012$ & GDP, tourism receipts & Tourism $\rightarrow$ Growth \\
\hline Hye and Khan (2013) & Pakistan & $1971-2008$ & GDP, tourism receipts & Tourism $\rightarrow$ Growth \\
\hline Kadir et al. (2012) & Malaysia & $1998-2005$ & GDP, tourism receipts & Tourism $\rightarrow$ Growth \\
\hline Khalil et al. (2007) & Pakistan & 1960-2005 & GDP, tourism receipts & Tourism $\leftrightarrow$ Growth \\
\hline Liu and Song (2018) & Hong Kong & $1974-2016$ & GDP, tourism receipts & Tourism $\leftrightarrow$ Growth \\
\hline Oh (2005) & Korean & $\begin{array}{l}\text { 1975:Q1- } \\
\text { 2001:Q1 }\end{array}$ & GDP, tourism receipts & Growth $\rightarrow$ Tourism \\
\hline Manzoor et al. (2019) & Pakistan & $1990-015$ & GDP, tourism receipts & Tourism $\rightarrow$ Growth \\
\hline Mohapatra (2018) & SAARC countries & $1995-2014$ & $\begin{array}{l}\text { GDP, tourism expenditure, } \\
\text { tourism receipts }\end{array}$ & Tourism $\rightarrow$ Growth \\
\hline Narayan (2010) & 4 Pacific islands & $1988-2004$ & GDP, tourism receipts & Tourism $\rightarrow$ Growth \\
\hline Nunkoo et al. (2020) & 545 estimates from 113 studies & $1972-2017$ & $\begin{array}{l}\text { GDP, tourism receipts, } \\
\text { tourism spending }\end{array}$ & Tourism $\rightarrow$ Growth \\
\hline Paramati et al. (2017) & Iran & $2005-2014$ & GDP, tourism receipts & Tourism $\rightarrow$ Growth \\
\hline Phiri (2016) & South Africa & $1995-2014$ & GDP, tourism expenditure & Tourism $\leftrightarrow$ Growth \\
\hline Ribeiro and Wang (2020) & Sao Tome & $1997-2018$ & GDP, tourism receipts & Tourism $\rightarrow$ Growth \\
\hline Risso (2018) & 179 countries & 1995-2016 & GDP, tourism expenditure & Tourism $\rightarrow$ Growth \\
\hline Roudi et al. (2019) & $\begin{array}{l}\text { 10 Small Island Developing } \\
\text { States (SIDSs) }\end{array}$ & 1995-2014 & GDP, tourism expenditure & Tourism $\rightarrow$ Growth \\
\hline Salawu (2020) & Nigeria & 1995- 2017 & & $\begin{array}{l}\text { Tourism } \rightarrow \text { Growth } \\
\text { Tourism } \neq \text { Growth } \\
\end{array}$ \\
\hline Seghir et al. (2015) & 49 countries & $1988-2012$ & GDP, tourism spending & Tourism $\leftrightarrow$ Growth \\
\hline Sokhanvar et al. (2018) & $\begin{array}{l}16 \text { emerging market } \\
\text { economies }\end{array}$ & 1995-2014 & GDP, tourism receipts & $\begin{array}{l}\text { Tourism } \leftrightarrow \text { Growth } \\
\text { Tourism } \neq \text { Growth }\end{array}$ \\
\hline Srinivasan et al. (2012) & Sri Lanka & 1969-2009 & GDP, tourism receipts & Tourism $\rightarrow$ Growth \\
\hline Su et al. (2021) & China & $2000-2019$ & GDP, tourism receipts & Tourism $\rightarrow$ Growth \\
\hline Tang and Tan (2015) & Malaysia & $1975-2011$ & GNP, tourism receipts & Tourism $\rightarrow$ Growth \\
\hline Tang and Tan (2018) & 167 countries & $1995-2013$ & GNP, tourism receipts & Tourism $\rightarrow$ Growth \\
\hline Ohlan (2017) & India & 1960-2014 & GDP, tourism expenditure & Tourism $\rightarrow$ Growth \\
\hline $\mathrm{Wu}$ and $\mathrm{Wu}(2018)$ & 12 western regions, China & $1995-2015$ & GNP, tourism receipts & Tourism $\leftrightarrow$ Growth \\
\hline Zuo and Huang (2018) & 31 provinces in China & $1995-2013$ & GNP, tourism receipts & Tourism $\leftrightarrow$ Growth \\
\hline
\end{tabular}

Notes: $\rightarrow$ represents unidirectional causality, $\leftrightarrow$ represents bi-directional causality, and $\neq$ represents non-causality 
In contrast to previous studies, in this study, the verification of the tourism-led growth hypothesis is tested using combination techniques of cointegration, Fully Modified Ordinary Least Square (FMOLS), and Granger causality provide more convincing empirical findings. This study's results are expected to shed some lights for the government in developing proper strategies to strengthen the tourism sector as the mainstay of the economic driving sector. In addition, the results of this study are also expected to enrich existing empirical evidence on tourism-economic growth nexus from the perspective of developing countries with the largest Muslim population in the world, namely Indonesia.

In the next section, the literature review of previous relevant studies will be provided, followed by the explanation of empirical frameworks consisting of data sources, model specifications, and econometrics methodology in Section 3. Section 4 provides results and discussion, and finally, section 5 concludes the paper.

\section{LITERATURE REVIEW}

Balaguer and Cantavella-Jordá (2002) were among the first researchers to investigate the causal relationship between tourism and economic growth in Spain and confirm the tourism-led growth hypothesis. Following this study, many scholars have increasingly been attracted to investigating the tourism-economic growth relationship worldwide. This paper specifically limits the literature review between tourism receipts and economic growth variables without including explanatory or other control variables. This literature review is sorted by country or continent group and is explained based on various methodologies examined in each country. The summary of the literature review is presented in Table 1.

For example, for countries in the Asian Region, Oh (2005) investigates the causality relationship between tourism revenue and economic growth for Korea's case. The study finds a non-causal relationship from tourism to economic growth, but the causality is found running from economic growth to the tourism sector. This confirms the non-validity of the tourism-led growth hypothesis for the Korean economy. In contrast, Khalil et al. (2007) and Manzoor et al. (2019) examine the causality relationship between tourism and economic growth in Pakistan and found a two-way causality between tourism and economic growth. Kadir et al. (2012) examine the relationship between tourism and economic growth in Malaysia using panel data on foreign tourist arrivals from neighbouring ASEAN-5 countries covering the 1998-2005 period. They found that the two variables were cointegrated in the long run. They also document a directional Granger causality, both in the short- and long-term, from international tourism's reception to economic growth. Meanwhile, Ohlan (2017), Paramati et al. (2017), Chulaphan and Barahona (2018), Liu and Song (2018), Ribeiro and Wang (2020), and Su et al. (2021) found a bidirectional causal relationship between tourism and economic growth for the cases of India, Iran, Thailand, Hong Kong, Sao Tome, China, respectively.

Furthermore, Srinivasan et al. (2012) examine the impact of tourism on Sri Lanka's economic growth during the period 1969-2009 using the ARDL-Error Correction Model. They found that tourism has a significant impact on economic growth both in the short- and long-term. Hye and Khan (2013) investigate the tourism-led growth hypothesis in Pakistan for the 1971-2008 period using the Johansen-Juselius cointegration and ARDL approaches based on the long-run causality test. They found that the two variables were cointegrated and had a direct causal relationship running from tourism to economic growth in the long run. Tang and Tan (2015) investigate the tourism-led growth hypothesis in Malaysia for 1975-2011 using the Granger causality method based on VECM. They found that the two variables were cointegrated, confirming the directional causality relationship running from tourism to long-term economic growth. Except for the Korean economy, findings for other Asian countries have confirmed the tourism-led growth hypothesis.

Moreover, previous studies from several European countries also confirm the tourism-led growth hypothesis. For example, Arslanturk et al. (2011) investigate the time-varying relationship between tourism revenue and economic growth and found a non-causal relationship between the two series. However, after the 1983s, there was a direct causality running from tourism revenue to economic growth. Eeckels et al. (2012) examine the relationship between tourism and economic growth in Greece for the period 1976-2004 using the VAR model and found that tourism revenues affected economic growth, a finding confirming the tourism-led growth hypothesis. Roudi et al. (2019) also supported these findings, who found the tourism-led growth hypothesis for the case of 10 Small Island Developing States (SIDSs). Dogru and Bulut (2018) examine the relationship between tourism and economic growth in seven European countries for 1996-2014 using the Dumitrescu and Hurlin (2012)'s causality method. They found a two-way causality between tourism revenue and economic growth for European countries. Other studies also documented a unidirectional causal relationship running from tourism to economic growth (Antonakakis et al., 2015; Tang and Tan, 2018; Risso, 2018; Antonakakis et al., 2019; Nunkoo et al., 2020) for the case of European and developed countries and a bidirectional relationship between tourism and economic growth (Seghir et al., 2015; Aratuo and Etienne, 2019) for the case of developed countries, including the United States. Similarly, for China, Wu and Wu (2018) and Zuo and Huang (2018) found a bidirectional causal relationship between tourism and economic growth.

In a similar vein, studies on the African countries by Balcilar et al. (2014) focused on the time-varying parameters of the relationship between tourism and economic growth in South Africa during the period 1960-2011 using the Granger causality method based on VECM. This study found no Granger causality for the full sample 1960-2011; instead, a twoway causality relationship was documented for the 1985-1990 sample period. The non-causal relationship between tourism and economic growth is also found by Salawu (2020) for the case of Nigeria, and the bidirectional causal relationship between the variables is also documented for the case of South Africa by Phiri (2016). For the Pacific Islands, Narayan (2010) investigates the relationship between tourism and economic growth for the four Pacific island nations. He found a direct causality running from tourism to economic growth; a finding supported the tourism-led growth hypothesis. Finally, Amaghionyeodiwe (2012) investigates the causal relationship between tourism revenue and Jamaica's economic growth for 
the period 1970-2005. Using the Johansen cointegration and VECM approach, he found that the two series of variables were co-integrated in the long run and had a unidirectional Granger causal relationship running from tourism to economic growth. Therefore, his findings confirm the tourism-led growth hypothesis for the Jamaican economy.

Furthermore, previous studies found a two-way causality between tourism revenue and economic growth for the cases of the Mediterranean and the OECD countries (Aslan, 2014; Bilen et al., 2017; Govdeli and Direkci, 2017). For example, Aslan (2014) investigate the relationship between tourism and economic growth in 12 Mediterranean countries using the Granger causality panel model for the 1995-2010 period. He found a two-way causality between tourism and economic growth in those countries. Bilen et al. (2017) investigate the relationship between tourism and economic growth in 12 Mediterranean countries for the period 1995-2012 using the Granger panel causality method and found a two-way causality between tourism and economic growth. Govdeli and Direkci (2017) examine the long-term relationship between tourism revenue and economic growth for 34 OECD countries during the 1997-2012 period using the cointegration panel and FMOLS methods. First, they found that the two variables were cointegrated.

Second, they also found that tourism had a positive and significant impact on economic growth in the long run. Finally, for the case of emerging economies, including Indonesia, Sokhanvar et al. (2018) investigate the causal relationship between tourism and economic growth for emerging economies using the Granger causality method during the 1995-2014 period. They found unidirectional causality running from tourism to economic growth for Brazil, Mexico, and the Philippines. In contrast, a unidirectional causality running from economic growth to the tourism sector is documented for the cases of China, India, Indonesia, Malaysia, and Peru. The study found no causal relationship between tourism and economic growth for Croatia, Hungary, Poland, Russia, South Africa, Thailand, and Turkey. Finally, Eyuboglu and Eyuboglu (2020) examine the asymmetrical relationship between tourism and economic growth for nine developing countries during the 1995-2016 period. They found unidirectional causality running from tourism to economic growth for Argentina and Turkey. Conversely, the study documented a non-causal tourism-economic growth nexus for Brazil, Croatia, Indonesia, Mexico, the Philippines, Russia, and South Africa.

The above-reviewed studies on various countries globally show the existence of four possible relationships between tourism and economic growth, namely: (i) a unidirectional relationship running from tourism to economic growth (tourismled growth hypothesis); (ii) i) a unidirectional relationship running from economic growth to tourism (growth-led tourism hypothesis); (iii) a bidirectional or two-way relationship between tourism and economic growth; and (iv) non-causal relationship between tourism and economic growth. Specifically, for the case of Indonesia, previous studies that use different data periods and methods (Sokhanvar et al., 2018; Eyuboglu and Eyuboglu, 2020) found evidence contradicting the tourism-led growth hypothesis. Motivated by the mixed findings of previous studies on tourism-growth nexus and an increasing contribution of tourism towards the national economy of Indonesia, this study intends to fill the existing gaps in the previous studies by identifying which kinds of nature of tourism-economic growth nexus exist for the case of Indonesia using an updated and longer data period (1995-2017) and combination techniques of cointegration, Fully Modified Ordinary Least Square (FMOLS), and Granger causality to provide more reliable empirical findings.

\section{DATA AND METHODOLOGY}

\section{DATA}

This study utilizes annual data over the period 1995-2017 sourced from the World Development Indicators (WDI)

Table 2. Measurements of variables and their sources

\begin{tabular}{|c|l|c|c|}
\hline Variable & \multicolumn{1}{|c|}{ Description } & Period & Source \\
\hline $\ln G D P$ & $\begin{array}{l}\text { Natural logarithm of Gross Domestic Product } \\
\text { (constant price 2010 USD) }\end{array}$ & $1995-2017$ & WDI, World Bank \\
\hline $\ln T R$ & Natural logarithm of Tourism Receipts (USD) & $1995-2017$ & WDI, World Bank \\
\hline
\end{tabular}

of the World Bank (2019). The data

measurements, periods and their sources are illustrated in Table 2. All data in this study are transformed into natural logarithmic measurements to ensure the normality of data distribution. This study is conducted to empirically measure and analyze the impact of tourism on economic growth in Indonesia. The variables used in this study consist of changes in Growth Domestic Product (GDP) to measure economic growth as the dependent variable and receipts from Tourist Visits (TR) to measure the tourism sector as an independent variable.

\section{Econometric models}

Following the studies by Kadir et al. (2012) and Tang and Tan (2015), to measure and analyze the relationship between tourism and economic growth, the study proposes the following basic empirical model

$$
G D P=f(T R) \quad \text { (1) } \begin{aligned}
& \text { where } G D P \text { is the real gross domestic product, and } \\
& \text { Equation (1) shows the GDP as a function of } T R \text {. }
\end{aligned}
$$

To measure the long-run relationship between tourism and economic growth in Indonesia, following Tang and Tan (2015), Equation (1) could be further re-written, as follows:

$$
\ln G D P_{t}=\beta_{0}+\beta_{l} \ln T R_{t}+\varepsilon_{t}
$$

where $\ln G D P$ is the natural logarithm of real gross domestic product, $\ln T R$ is the natural logarithm of tourism receipts, $\beta_{0}$ is the constant term, $\beta_{1}$ is the estimated regression coefficient, and $\varepsilon$ is the error term.

Equation (2) shows the econometric model predicting the long-run GDP-TR relationship. Before estimating a dynamic time series model, the stationarity of the data is tested in the first step. In the time series analysis, data stationarity testing is important to avoid spurious regression. Stationary testing procedures were first introduced by Dickey and Fuller (1979, 
1981). To ensure that all variables used for estimation are stationary to the same degree, this study applies a test based on the Augmented Dickey-Fuller (ADF) method. Data from each variable is first tested at an order zero, $I(0)$. If the tested variable is non-stationary at the $I(0)$, the study continues testing the stationarity of the variable in the first-order, $I(1)$ and in the second-order, I(2) (Majid, 2007; Yusof and Majid, 2007; Majid and Kassim, 2015). Data non-stationarity is tested at the probability value greater than the significance level $\alpha>0.01 ; \alpha>0.05$; and $\alpha>0.10$.

In the second step, the existence of the number of cointegration relationships between series is examined. Cointegration is a linear combination of non-stationary variables. Engle and Granger (1987) first introduced the cointegration test, which aims to find out cointegration or long-term balance between two or more variables that are non-stationary. In this study, Johansen (1991, 1995)'s cointegration test is used to investigate the long-term relationship between independent variables and the dependent variable. If there is no cointegration relationship, an unrestricted VAR model can be applied. However, if there is a cointegration relationship between variables, the Vector Error Correction (VECM) model is used.

In the third step, the study investigates the long-term and Granger causal relationship using the VECM. If cointegrated in I(1), one alternative method is to use the FMOLS method developed by Phillips and Hansen (1990). FMOLS is superior to OLS because it provides consistent predictors, control individual effects, and correct endogenous errors.

Finally, to determine whether there is a relationship between series in econometric modelling, the Granger causality test (Granger, 1969) through the VECM framework is performed. In matrix form, the VECM equation to test Granger causality between tourism and economic growth is proposed as follows:

$$
\left[\begin{array}{c}
\Delta \ln G D P_{t} \\
\Delta \ln T R_{t}
\end{array}\right]=\left[\begin{array}{l}
\beta_{1} \\
\beta_{2}
\end{array}\right]+\sum_{i=1}^{p}\left[\begin{array}{ll}
\partial_{11} & \partial_{12} \\
\partial_{21} & \partial_{22}
\end{array}\right] \times\left[\begin{array}{c}
\Delta \ln G_{t-1} \\
\Delta \ln T R_{t-1}
\end{array}\right]+\left[\begin{array}{l}
\delta_{1} \\
\delta_{2}
\end{array}\right] E C T_{t-1}+\left[\begin{array}{l}
\varepsilon_{1 t} \\
\varepsilon_{1 t}
\end{array}\right]
$$

where $\Delta$ is the lag operator of all variables, $\beta$ is the lag independent variable's coefficient, $\delta$ is the lag of the cointegrated variable, and $\varepsilon$ is the error term.

\section{FINDINGS AND DISCUSSION Descriptive statistics}

A summary of statistics to illustrate the characteristics of the data used in this study is presented in Table 3. During the observation period, the value of Indonesia's real gross domestic product (GDP) ranged between USD 428.76 billion and USD 1,090.45 billion, with an average value of USD 665.22 billion. Furthermore, the value of tourism receipts is between USD4.26 billion and USD 14.12 billion, with an average value of USD 7.35 billion.

\section{Results of unit root test}

Based on the previous section's research model, the first step that must be performed is to test the stationarity of the data. The stationarity test is essential to identify whether there is a root unit in the time series data used. This test aims to determine the possibility of time-series data used in the study contain unit root or non-stationarity. Non-stationary data imply that it allows good regression results, but is unable to describe the actual state. The test is carried out at the level stage up to the first difference using the lag-length of 4 based on the Schwarz Information Criterion (SIC) criterion. The Augmented Dickey-Fuller (ADF) method is applied to test the unit root level based on the intercept and trend equations. The results of the unit root test are presented in Table 4.

Table 4 shows that all variables are non-stationarity at the level. Therefore, the next step must be done by testing at the first difference level to ensure all variables are stationary. In this stage, the $\ln G D P$ and $\ln T R$ are found to become stationary at the first difference level. Thus, in the next step, the cointegration test could be performed.

Table 4. Augmented Dickey-Fuller (ADF) test

\begin{tabular}{|c|c|c|c|c|c|}
\hline \multirow{2}{*}{} & \multicolumn{2}{|c|}{ Constant } & & \multicolumn{2}{c|}{ Constant and trend } \\
\cline { 2 - 5 } & Level & First difference & & Level & First difference \\
\hline $\ln G D P$ & -0.9225 & $-3.1796^{*}$ & -1.0933 & $-10.5046^{* *}$ \\
\hline $\ln T R$ & 0.9457 & $-5.6363^{* *}$ & & -2.1493 & $-6.1107^{* *}$ \\
\hline
\end{tabular}

Note: ${ }^{* *}$ and ${ }^{*}$ indicate significance at the $1 \%$ and $5 \%$ levels, respectively. The lag order for the ADF test is selected based on the Schwarz Information Criterion (SIC).

Note: ${ }^{* * *}$ indicates significance at the $1 \%$ level. The trend assumption uses a linear deterministic trend. The lag interval (in first differences) is 1 to 2.
Table 5. Johansen cointegration tests

\begin{tabular}{|c|c|c|c|c|c|}
\hline \multicolumn{5}{|c|}{ Unrestricted cointegration rank test (Trace value) } \\
\hline \multicolumn{2}{|c|}{ Hypothesis } & \multirow{2}{*}{ Eigenvalue } & Trace & Critical Value & Probabilit \\
\cline { 1 - 3 } $\mathbf{H}_{\mathbf{0}}$ & $\mathbf{H}_{\mathbf{1}}$ & & Statistic & $\mathbf{( 0 . 0 5 )}$ & $\mathbf{y}$ \\
\hline $\mathrm{r} \leq 0$ & $\mathrm{r}>1$ & 0.9694 & $75.7184^{* * * *}$ & 15.4947 & 0.0000 \\
\hline $\mathrm{r} \leq 1$ & $\mathrm{r}>2$ & 0.3927 & $9.4757^{* * *}$ & 3.8415 & 0.0021 \\
\hline
\end{tabular}

Unrestricted cointegration rank test (Maximum Eigenvalue)

\begin{tabular}{|c|c|c|c|c|c|}
\hline \multicolumn{2}{|c|}{ Hypothesis } & \multirow{2}{*}{ Eigenvalue } & \multirow{2}{*}{\begin{tabular}{|c|} 
Max-Eigen \\
Statistic \\
\end{tabular}} & \multirow{2}{*}{$\begin{array}{l}\text { Critical Value } \\
(0.05) \\
\end{array}$} & \multirow{2}{*}{$\begin{array}{c}\text { Probabilit } \\
\mathbf{y}\end{array}$} \\
\hline $\mathbf{H}_{0}$ & $\mathrm{H}_{1}$ & & & & \\
\hline $\mathrm{r} \leq 0$ & & & $662426^{*}$ & 14.2646 & \\
\hline $\mathrm{r} \leq 1$ & $r>2$ & 0.5921 & & 3.8415 & 0.0021 \\
\hline
\end{tabular}

\section{Results of the cointegration test}

After ensuring all variables are stationary at the first difference, the long-term relationship between the series of variables is investigated using the Johansen cointegration method. This test is done by comparing the Trace statistics and its critical value. If the trace statistic is greater than the critical value, then the equation is cointegrated. The findings of the cointegration test are reported in Table 5. As illustrated in Table 5, the value of Trace statistic and Maximum Eigenvalue at $\mathrm{r} \leq 0$ and $\mathrm{r} \leq 1$ is greater than the critical value with a significance level of $1 \%$. This means that the null hypothesis of no 
cointegration is rejected, while the alternative hypothesis of cointegration cannot be rejected. Based on Johansen's cointegration test, the two variables contained cointegration at a $1 \%$ level of significance. Thus, this indicates stability or a balanced relationship between the GDP and TR in the long run. In other words, in each short-term period, all variables adjust to each other to achieve their long-term equilibrium. This finding also implies that to predict the future movement of economic growth, it could be done by predicting the changes in the tourism sector in Indonesia.

\section{Findings from the FMOLS}

After ensuring that the variables of tourism revenue and economic growth are co-integrated, in this section, the study investigates the long-term impact of tourism revenue on economic growth. The findings of the long-term elasticity of the impact of tourism revenue on economic growth using the FMOLS method based on Phillips and Hansen (1990)'s framework is reported in Table 6 . Table 6 reports that the cointegration regression estimation with the FMOLS model. The study found the cointegration between tourism revenue and economic growth. First, tourism revenue elasticity is 0.06 . Second, statistically, tourism revenue has a positive and significant impact on Indonesia's economic growth in the long run. These findings indicate that a $1 \%$ increase in tourism revenue has led to a $0.06 \%$ increase in economic growth. In a declining trend of the contribution of the oil and gas sector to the national economy, the government should focus on further promoting the tourism sector, as it has positively contributed to the increase in economic growth. This finding shows the robustness of the long-term relationship between tourism revenue and Indonesia's economic growth for the 1995-2017 period. Our findings are consistent with the study of Govdeli and Direkci (2017) for the economy of the OECD countries; Mohapatra (2018) for the economy of the SAARC group of countries; and Narayan (2010) for the Pacific Islands economy.

Table 6. Modified ordinary least square (FMOLS) test

\begin{tabular}{|c|c|c|c|c|}
\hline Variable & Coefficient & Standard Error & t-Statistic & Probability \\
\hline $\ln T R$ & 0.0635 & $0.0288^{* * *}$ & 2.2058 & 0.0406 \\
\hline Constant & 0.0473 & $0.0048^{* * * *}$ & 9.8039 & 0.000 \\
\hline R-squared & 0.7842 & Mean dependent variance & 0.0399 \\
\hline Adjusted R-squared & 0.7602 & \multicolumn{2}{|c|}{ S.D. dependent variance } & 0.0429 \\
\hline S.E. of regression & 0.021 & \multicolumn{2}{|c|}{ Long-run variance } & 0.0004 \\
\hline
\end{tabular}

Note: ${ }^{* * *}$ and ${ }^{* *}$ indicate significance at $1 \%$ and $5 \%$ levels, respectively. The long-run covariance estimate is based on the Bartlett Kernel (Newey-West) fixed bandwidth $=3.0000$.
Table 7. Results of the Granger causality based on the VECM framework

\begin{tabular}{|c|c|c|c|}
\hline \multirow{2}{*}{$\begin{array}{c}\text { Dependent } \\
\text { variable }\end{array}$} & \multicolumn{2}{|c|}{ Short-run } & Long-run \\
\cline { 2 - 4 } & $\Delta \ln \boldsymbol{G D P}$ & $\Delta \ln \boldsymbol{T R}$ & $\boldsymbol{E C T}_{\boldsymbol{t}-1}$ \\
\hline$\Delta \ln G D P$ & - & $10.9572^{* * *}$ & $-0.0951^{* * *}$ \\
\hline & & {$[18.678]$} & $(-9.1430)$ \\
\hline$\Delta \ln T R$ & 4.5076 & - & $-0.0588^{* *}$ \\
\hline & {$[1.1897]$} & & $(-2.3104)$ \\
\hline
\end{tabular}

Note: ${ }^{* * *}$ and ${ }^{* *}$ indicate significance at the $1 \%$ and $5 \%$ levels, respectively. Figures in parentheses and square brackets represent t-statistics and F-statistics, respectively.

\section{Results of Granger causality}

To confirm the presence of a long-term relationship, a Granger causality test is performed to identify whether the two variables have a direct, reciprocal, and independent relationship or not. In other words, does one variable have a significant causal relationship with other variables because each variable in the study has the opportunity to become an endogenous or exogenous variable? The Granger causality test in this study is conducted based on the VECM Granger causality framework using Wald tests' block exogeneity with a significant level of $1 \%$. The findings of the Granger causal relationship between tourism and economic growth is reported in Table 7. Referring to Table 7, the study could summarize the following findings. First, the findings show that, in the short term, there is a causal relationship between tourism revenue and economic growth. A unidirectional causal relationship running from tourism revenue to economic growth is documented at the significance level of $1 \%$. Second, there is also a causal effect of tourism revenue on economic growth at the $1 \%$ level of significance in the long run. These findings confirm the tourism-led growth hypothesis.

These empirical evidences suggest that to promote sustainable economic growth in Indonesia, efforts must be made to enhance its tourism sector. The government should aggressively promote tourism to foreign tourists by strengthening national tourism branding and intensifying various forms of advertising, selling, incentive access, and hot deals. The government must also participate in promoting Indonesia in world tourism exhibition events. Besides, strengthening the tourism sector can also be done by realizing border tourism, tourism hub, and Low-Cost Carrier Terminal (LCCT). Border tourism is intended to attract foreign tourists from neighbouring countries. In contrast, the tourism hub is intended to be a transit area for tourists who fly between countries by cooperating with wholesalers, such as travel agents, by holding tourism exhibitions in malls and digital marketing. Finally, the LCCT must also be realized immediately to make it easier for many budget airlines to fly to Indonesia with foreign tourists. Commonly, people will go on vacation because of two main reasons, namely cheaper flight ticket and short distance. LCCT will make Indonesia a tourist destination that is cheaper and easier to reach by tourists using budget airlines.

The finding of tourism-led growth hypothesis for Indonesia is in line with previous studies such as Balaguer and Cantavella-Jordá (2002) for the Spanish economy, Kadir et al. (2012), Tang and Tan (2015) for the Malaysian economy, and Roudi et al. (2019) for the case of 10 Small Island Developing States (SIDSs). Our finding is also supported by studies on European and developed economies who documented a unidirectional causal relationship running from tourism to economic growth (Antonakakis et al., 2015; Tang and Tan, 2018; Risso, 2018; Antonakakis et al., 2019; Nunkoo et al., 2020). These findings showed that tourism plays an important role in promoting the national economy.

\section{CONCLUSION}

This study examined and analyzed the relationship between tourism and economic growth for the Indonesian 
economy using various time series techniques during the 1995-2017 period. For this purpose, batteries of time series tests have been conducted. Based on the Johansen cointegration test, the study found a cointegration between tourism revenue and economic growth. Based on the FMOLS, tourism revenue is found to have a positive and statistically significant impact on economic growth. Finally, based on the Granger causality test within the VECM framework, the study found a unidirectional causal relationship running from tourism revenue to economic growth, both in the short and long term, supporting the tourism-led growth hypothesis. This empirical study offers a piece of new evidence for the tourism-led growth hypothesis for Indonesia's case. Besides, this finding can also indicate the importance of promoting the tourism industry to enhance Indonesia's national economy. Realizing the importance of tourism in the economy, it is suggested that the government and the private sector can work together to develop international tourism destinations so that they can truly realize sustainable economic growth driven by tourism in the future. The development of international tourism should not only impact other related sectors, but it should also increase domestic income.

To further enhance the tourism sector's contribution to Indonesia's economy, the government should design proper strategies to attract more foreign tourists, supported by travel agencies and tourism associations nationwide. The government should also enhance national tourism branding through various forms of e-advertising. The national tourism board should regularly promote Indonesia as the world's best tourism destination in world tourism exhibition events. Besides, the national tourist board should provide more attractive and diversified incentive access or tourists. Enhancing border tourism, tourism hub, and Low-Cost Carrier Terminal (LCCT) could also attract foreign tourists from neighbouring countries and make Indonesia a tourism transit area and destination that is easily reached with budget airlines. The future studies on this topic could incorporate more explanatory variables related to tourism into the analysis to provide more comprehensive empirical findings. Comparative studies on this issue between regions of the country based on their per capita income status or other categories could also provide new perspectives for the tourism-led growth hypothesis.

\section{Acknowledgements}

This study is part of the research funded by the Directorate of Research and Community Service - Ministry of Research, Technology and Higher Education, the Republic of Indonesia under the Doctoral Dissertation Research Grant Scheme, No. 99/UN54.6/LT/2018.

\section{REFERENCES}

Amaghionyeodiwe, L.A. (2012). Research note: A causality analysis of tourism as a long-run economic growth factor in Jamaica. Tourism Economics, 18(5), 1125-1133. https://doi.org/10.5367\%2Fte.2012.0155

Antonakakis, N., Dragouni, M., \& Filis, G. (2015). How strong is the linkage between tourism and economic growth in Europe?. Economic Modelling, 44, 142-155. https://doi.org/10.1016/j.econmod.2014.10.018

Antonakakis, N., Dragouni, M., Eeckels, B., \& Filis, G. (2019). The tourism and economic growth enigma: examining an ambiguous relationship through multiple prisms. Journal of Travel Research, 58(1), 3-24. https://doi.org/10.1177/0047287517744671

Aratuo, D.N., \& Etienne, X.L. (2019). Industry level analysis of tourism-economic growth in the United States. Tourism Management, 70, 333-340. https://doi.org/10.1016/j.tourman.2018.09.004

Arslanturk, Y., Balcilar, M., \& Ozdemir, Z.A. (2011). Time-varying linkages between tourism receipts and economic growth in a small open economy. Economic Modelling, 28(1-2), 664-671. https://doi.org/10.1016/j.econmod.2010.06.003

Aslan, A. (2014). Tourism development and economic growth in the Mediterranean countries: evidence from panel Granger causality tests. Current Issues in Tourism, 17(4), 363-372. https://doi.org/10.1080/13683500.2013.768607

Balaguer, J., \& Cantavella-Jordá, M. (2002). Tourism as a long-run economic growth factor: the Spanish case. Applied Economics, 34(7), 877-884. https://doi.org/10.1080/00036840110058923

Balcilar, M., Van Eyden, R., Inglesi-Lotz, R., \& Gupta, R. (2014). Time-varying linkages between tourism receipts and economic growth in South Africa. Applied Economics, 46(36), 4381-4398. https://doi.org/10.1080/00036846.2014.957445

Bilen, M., Yilanci, V., \& Eryüzlü, H. (2017). Tourism development and economic growth: a panel Granger causality analysis in the frequency domain. Current Issues in Tourism, 20(1), 27-32. https://doi.org/10.1080/13683500.2015.1073231

Chulaphan, W., \& Barahona, J.F. (2018). Contribution of disaggregated tourism on Thailand's economic growth. Kasetsart Journal of Social Sciences, 39(3), 401-406. https://doi.org/10.1016/j.kjss.2017.07.012

Dickey, D.A., \& Fuller, W.A. (1979). Distribution of the estimators for autoregressive time series with a unit root. Journal of the American Statistical Association, 74(366a), 427-431. https://doi.org/10.1080/01621459.1979.10482531

Dickey, D.A., \& Fuller, W.A. (1981). Likelihood ratio statistics for autoregressive time series with a unit root. Econometrica, 49(4), 1057-1072. https://doi.org/10.2307/1912517

Dogru, T., \& Bulut, U. (2018). Is tourism an engine for economic recovery? Theory and empirical evidence. Tourism Management, 67, 425-434. https://doi.org/10.1016/j.tourman.2017.06.014

Dumitrescu, E.I., \& Hurlin, C. (2012). Testing for Granger non-causality in heterogeneous panels. Economic Modelling, 29(4), 14501460. https://doi.org/10.1016/j.econmod.2012.02.014

Eeckels, B., Filis, G., \& Leon, C. (2012). Tourism income and economic growth in Greece: Empirical evidence from their cyclical components. Tourism Economics, 18(4), 817-834. https://doi.org/10.5367\%2Fte.2012.0148

Eyuboglu, S., \& Eyuboglu, K. (2020). Tourism development and economic growth: an asymmetric panel causality test. Current Issues in Tourism, 23(6), 659-665. https://doi.org/10.1080/13683500.2019.1588863

Granger, C. W. (1969). Investigating causal relations by econometric models and cross-spectral methods. Econometrica, 37(3), 424-438. https://doi.org/10.2307/1912791

Hurri, S., Muhammad, S., Jamal, A., \& Majid, M.S.A. (2019). Do exports of oil and gas still matter for regional economic growth of Sumatra, Indonesia? Regional Science Inquiry, 11(2), 9-18. http://www.rsijournal.eu/ARTICLES/June_2019/SI/1.pdf

Hye, Q.M.A., \& Khan, R.E.A. (2013). Tourism-led growth hypothesis: A case study of Pakistan. Asia Pacific Journal of Tourism Research, 18(4), 303-313. https://doi.org/10.1080/10941665.2012.658412 
Johansen, S. (1991). Estimation and hypothesis testing of cointegration vectors in Gaussian vector autoregressive models. Econometrica, 59(6), 1551-1580. https://doi.org/10.2307/2938278

Johansen, S. (1995). Likelihood-based Inference in Cointegrated Vector Autoregressive Models. Oxford: Oxford University Press.

Kadir, N., Zaini, M., \& Karim, A. (2012). Tourism and economic growth in Malaysia: Evidence from tourist arrivals from ASEAN-5. Economic Research, 25(4), 1089-1100. https://doi.org/10.1080/1331677X.2012.11517550

Kang, S., Kim, J., \& Nicholls, S. (2014). National tourism policy and spatial patterns of domestic tourism in South Korea. Journal of Travel Research, 1-14. https://doi.org/10.1177\%2F0047287514522875

Khalil, S., Kakar, M.K., \& Waliullah. (2007). Role of tourism in economic growth: Empirical evidence from Pakistan economy. Pakistan Development Review, 46(4), 985-995. https://www.jstor.org/stable/41261208

Liu, H., \& Song, H. (2018). New evidence of dynamic links between tourism and economic growth based on mixed-frequency granger causality tests. Journal of Travel Research, 57(7), 899-907. https://doi.org/10.1177/0047287517723531

Majid, M.S.A. (2007). Does financial development cause economic growth in the ASEAN-4 countries?. Savings and Development, 31(4), 369-398. https://www.jstor.org/stable/41406460

Majid, M.S.A., \& Kassim, S.H. (2015). Assessing the contribution of Islamic finance to economic growth: Empirical evidence from Malaysia. Journal of Islamic Accounting and Business Research, 6(2), 292-310. https://doi.org/10.1108/JIABR-07-2012-0050

Manzoor, F., Wei, L., \& Asif, M. (2019). The contribution of sustainable tourism to economic growth and employment in Pakistan. International journal of environmental research and public health, 16(19), 3785. https://doi.org/10.3390/ijerph16193785

Mohapatra, S. (2018). Investigating the tourism and economic growth linkage: a panel causality analysis for the SAARC countries. Asia Pacific Journal of Tourism Research, 23(6), 573-583. https://doi.org/10.1080/10941665.2018.1468345

Narayan, P.K. (2010). Tourism and economic growth: a panel data analysis for Pacific Island countries. Tourism Economics, 16(1), 169183. https://doi.org/10.5367\%2F000000010790872006

Nunkoo, R., Seetanah, B., Jaffur, Z.R.K., Moraghen, P.G.W., \& Sannassee, R.V. (2020). Tourism and economic growth: A metaregression analysis. Journal of Travel Research, 59(3), 404-423. https://doi.org/10.1177/0047287519844833

Oh, C.O. (2005). The contribution of tourism development to economic growth in the Korean economy. Tourism Management, 26(1), 39-44. https://doi.org/10.1016/j.tourman.2003.09.014

Ohlan, R. (2017). The relationship between tourism, financial development and economic growth in India. Future Business Journal, 3(1), 9-22. https://doi.org/10.1016/j.fbj.2017.01.003

Paramati, S.R., Alam, M.S., \& Chen, C.F. (2017). The effects of tourism on economic growth and CO2 emissions: a comparison between developed and developing economies. Journal of Travel Research, 56(6), 712-724. https://doi.org/10.1016/j.fbj.2018.09.001

Phillips, P.C.B., \& Hansen, B.E. (1990). Statistical inference in instrumental variables regression with I (1) Processes. Review of Economic Studies, 57(1), 99-125. https://doi.org/10.2307/2297545

Phiri, A. (2016). Tourism and Economic Growth in South Africa: Evidence from Linear and Nonlinear Cointegration Frameworks. International Research Journal, 14(1), 31-53. http://www.fm-kp.si/zalozba/ISSN/1581-6311/14_1.htm

Ribeiro, E.D.C., \& Wang, B. (2020). Tourism led growth hypothesis: Has the tourism industry an impact on the economic growth of Sao Tome and Principe?. International Journal of Economics and Financial Issues, 10(1), 180-185. https://doi.org/10.32479/ijefi.9105

Risso, W.A. (2018). Tourism and economic growth: A worldwide study. Tourism Analysis, 23(1), 123-135. https://doi.org/10.3727/ $108354218 X 15143857349828$

Roudi, S., Arasli, H., \& Akadiri, S.S. (2019). New insights into an old issue-examining the influence of tourism on economic growth: evidence from selected small island developing states. Current Issues in Tourism, 22(11), 1280-1300. https://doi.org/10.1080/ 13683500.2018.1431207

Salawu, M.K. (2020). Tourism and Economic Growth in African Largest Economy. Eurasian Journal of Economics and Finance, 8(2), 68-84. https://doi.org/10.15604/ejef.2020.08.02.002

Seghir, G.M., Mostéfa, B., Abbes, S.M., \& Zakarya, G.Y. (2015). Tourism spending-economic growth causality in 49 countries: A dynamic panel data approach. Procedia Economics and Finance, 23, 1613-1623. https://doi.org/10.1016/S2212-5671(15)00402-5

Sokhanvar, A., Çiftçioğlu, S., \& Javid, E. (2018). Another look at tourism-economic development nexus. Tourism Management Perspectives, 26, 97-106. https://doi.org/10.1016/j.tmp.2018.03.002

Srinivasan, P., Kumar, P.K.S., \& Ganesh, L. (2012). Tourism and economic growth in Sri Lanka: An ARDL bounds testing approach. Environment and Urbanization Asia, 3(2), 397-405. https://doi.org/10.1177\%2F0975425312473234

Su, Y., Cherian, J., Sial, M.S., Badulescu, A., Thu, P.A., Badulescu, D., \& Samad, S. (2021). Does tourism affect economic growth of China? A panel Granger causality approach. Sustainability, 13(3), 1349. https://doi.org/10.3390/su13031349

Tang, C.F., \& Tan, E.C. (2015). Does tourism effectively stimulate Malaysia's economic growth? Tourism Management, 46, $158-163$. https://doi.org/10.1016/i.tourman.2014.06.020

Tang, C.F., \& Tan, E.C. (2018). Tourism-led growth hypothesis: A new global evidence. Cornell Hospitality Quarterly, 59(3), 304-311. https://doi.org/10.1177/1938965517735743

Wu, T.P., \& Wu, H.C. (2018). The causal nexus between international tourism and economic development. Tourism Analysis, 23(1), 1729. https://doi.org/10.3727/108354218X15143857349468

Yusof, R.M., \& Majid, M.S.A. (2007). Macroeconomic variables and stock returns in Malaysia: An application of the ARDL bound testing approach. Savings and Development, 31(4), 449-469. https://www.jstor.org/stable/41406464

Zuo, B., \& Huang, S. (2018). Revisiting the tourism-led economic growth hypothesis: The case of China. Journal of Travel Research, 57(2), 151-163. https://doi.org/10.1177/0047287516686725

***World Bank. (2019). World Development Indicators. Retrieved December 7, 2019, https://data.worldbank.org/indicator/ST.INT.RCPT.CD

***World Tourism Organization. (2018). UNWTO Tourism Highlights, 2018 Edition. Madrid: UNWTO. https://doi.org/10.18111/ 9789284419876

Article history: Received: 06.01.2021 Revised: 06.05.2021 Accepted: 16.08.2021 Available online: 03.09.2021 